\title{
Development of Adult Forms of Attention Deficit Hyperactivity Disorder are Based on the Synaptic Disturbances During Brain Maturation: A Hypothesis
}

\author{
Uzbekov $\mathbf{M}^{*}$ and Zabludovsky A \\ Department of Brain Pathology, Moscow Research Institute of Psychiatry, Moscow, Russia \\ *Corresponding author: Uzbekov M, Department of Brain Pathology, Moscow Research Institute of Psychiatry, Moscow, Russia
}

\begin{tabular}{|c|c|}
\hline ARTICLE INFO & ABSTRACT \\
\hline Received: 幽 November 26, 2019 & Citation: Uzbekov M, Zabludovsky A. Development of Adult Forms of Attention Deficit \\
\hline Published: 櫘 December 03, 2019 & $\begin{array}{l}\text { Hyperactivity Disorder are Based on the Synaptic Disturbances During Brain Maturation: } \\
\text { A Hypothesis. Biomed J Sci \& Tech Res 23(3)-2019. BJSTR. MS.ID.003910. }\end{array}$ \\
\hline
\end{tabular}

\section{Introduction}

Some time ago we have put a question why about $20-30 \%$ of children Attention Deficit Hyperactivity Disorder (ADHD) transformed in adult forms with problems related to social adjustment and functioning (substance abuse and personality disorder) together with psychiatric problems [1,2]. We decided to shed some light on this problem using an animal model of ADHD. Earlier it was shown by us that prenatally alcoholic rat can serve as an adequate model for investigating of ADHD pathogenesis [3]. Our and literature data have shown that monoaminergic systems are integral components of pathogenetic mechanisms of ADHD. Proceed from this assumption we wanted to investigate the synaptic mechanisms involvement in these processes.

\section{Aim}

The aim of the study was to investigate postnatal developmental dynamics of the state of postsynaptic serotonergic receptors (5-HT1-R) and Synaptic Plasma Membrane (SPM) phosphorylation in prenatally alcoholised rat offspring.

\section{Material and Methods}

Experiments were performed on prenatally alcoholic rat offspring of dams which throughout the gestational period received a $10 \%$ solution of ethanol as a sole source of liquid (alcoholised offspring). Each dam received approximately 5.5 - $6.0 \mathrm{~g}$ of ethanol/1 kg per day [4]. Alcoholised offspring were taken into the experiment on the 30th, 60th and 90th Postnatal Days (PD). Serotonin binding with 5-HT1- R was measured using 3H-serotonin and SPM phosphorylation - using 32P- $\gamma$-ATP in hippocampus and cerebral cortex [5].

\section{Results}

$3 \mathrm{H}$-serotonin binding was increased in hippocampus significantly only at PD 60 and 90 by 27 and 36\% (p=0.05 both), respectively and in cerebral cortex only at PD 90 by $62 \%(p=0.01)$. Inhibition of SPM phosphorylation was revealed only at postnatal day 90 and was decreased significantly for 54 and 65\% (p=0.01) in hippocampus and cerebral cortex, respectively, as compared with controls.

\section{Discussion}

We found that prenatal alcoholisation resulted in changes of serotonin binding and SPM phosphorylation parameters in synaptic structures in different brain regions only at the late stages of postnatal development (early adulthood). We hypothesized that the delayed manifestation of neurochemical impairments in alcoholised rat offspring (ADHD model) proved that the brain could not manage the demands placed on it. We believe that there are a number of "masked" or "silent" disturbances in ADHD children that manifest themselves later in life. These disturbances are compensated by different adaptive brain mechanisms. Early adulthood is a critical period of human life. There appear the new demands for the brain - endogenous, environmental and social. If these demands exceed the threshold of compensation capabilities, then the adaptive mechanisms become broken. When 
different maturational factors influence on the brain in the state of disorganized developmental and metabolic processes that can facilitate the expression of the qualitatively new symptoms of ADHD: antisocial behavior, psychopathy and drug abuse [1-3].

\section{Conclusion}

We hypothesize that our findings of synaptic disturbances in ADHD model that revealed after 90 postnatal days can serve as a basis of pathological events that take place in adult ADHD subjects.

\section{References}

1. Barkley RA (2004) Driving impairments in teens and adults with attention deficit hyperactivity disorder. Psychiatr Clin North Am 27(2): 233-260.

ISSN: 2574-1241

DOI: $10.26717 /$ BJSTR.2019.23.003910

Uzbekov M. Biomed J Sci \& Tech Res

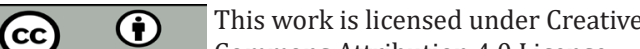
Submission Link: https://biomedres.us/submit-manuscript.php
2. Muglia P, JainUu, Macciardi F, Kennedy JL (2000) Adult attention deficit hyperactivity disorder and dopamine D4 receptor gene. Am J Med Genet 96(3): 273-277.

3. Uzbekov M (2006) The hyperkinetic syndrome as a manifestation of a developmental disturbances of brain monoaminergic systems. In Attention-Deficit Hyperactivity Disorder and the Hyperkinetic Syndrome. Current Ideas and Ways Forward (R.D. Oades, ed.), Nova Science Publishers, New York, USA, pp. 133-154.

4. Uzbekov MG, Moshanskaya MA, Wiechert P (1991) Monoamine metabolism and antenatal pathology in the brain development of rat offspring. In: Signal molecule and behavior (Winlow W, Vinogradova OS and Sakharov DA, eds.), Manchester University Press, Manchester and New York, USA, pp 259-262.

5. Uzbekov MG, Murphy S, Rose SPR (1979) Ontogenesis of serotonin receptors in different regions of rat brain. Brain Res 168(1): 195-199.

$\begin{array}{ll}\text { BIOMEDICAL } & \text { Assets of Publishing with us } \\ \text { RESEARCHES } & \text { - Global archiving of articles } \\ & \text { - Immediate, unrestricted online access } \\ \end{array}$

